IP Periodica Polytechnica

Social and Management

Sciences

23(2), pp. 106-112, 2015

DOI: $10.3311 /$ PPso. 7473

Creative Commons Attribution (i)

RESEARCH ARTICLE

\section{Education of Students of the Study Program Informatics in the Field of Corporate Social Responsibility}

\author{
Emese Tokarčíková ${ }^{*}$, Alžbeta Kucharčíková ${ }^{1}$, Mária Ďurišová ${ }^{1}$
}

Received 08 April 2014; accepted 29 November 2014

\begin{abstract}
Universities as the centres of knowledge play an important role in education and application of the concept of corporate social responsibility (CSR). They are not just institutions of higher education and research granting titles but they together educate responsible people with excellent knowledge able to solve questions and problems globally and share their knowledge that the wider community can benefit from. The aim of this article is to show which teaching methods could be used to educate students of the study program Informatics in the field of corporate social responsibility in Slovakia. The success of the CSR implementation, to a large extent, depends on the level of involvement of university teachers and appropriate teaching methods they choose. Corporate social responsibly literacy means, that student will be able to apply basic concepts years later in situations relevant to their professional personal lifeline.
\end{abstract}

\section{Keywords}

economics education, social entrepreneurship, teaching methods learning and teaching, engineering education

\footnotetext{
${ }^{1}$ Department of Macro and Microeconomics, Faculty of Management Science and Informatics, University of Žilina, Univerzitná 8215/1, 01026 Žilina, Slovak Republic

*Corresponding author, e-mail: Emese.Tokarcikova@fri.uniza.sk
}

\section{Introduction}

Universities belong to the major player in society-wide and economic life of the country and have an irreplaceable role in interaction with the surrounding for its economic, cultural and social development. Intellectual, cultural, as well as material and social standard of the nation was every time determined by the level of education. Educational and research activities of universities lead to the improvement of human potential and production of knowledge connected to innovation and excellence. "Effective management of innovation processes encourages innovative activities in business and will bring it expected results in the future" (Lendel and Varmus, 2013). Today, the role of universities is also to draw attention of the society to restored socio-economic and ecological problems of the world. Questions considering the provision of the protection of the environment, promotion of future generations and establishing sustainable development cannot remain only a part of the academic debates, but they must feature between the interests of businesses and state. Education on study programs related to Informatics allows acquisition and the subsequent opportunity of arraying out interesting and well paid profession, which is very desirable among young people. "The growing importance to increase the ability to match education alternatives with career options generates necessity to provide even students of Informatics with opportunities to use economic and managerial skills to solve meaningful problems.” (Tokarčíková, 2013) Students of the study programs of Informatics once will be employed as a project manager or will have your own business, so as a manager will communicate with potential partners and their employees actively and join them into the cooperation creation." (Vodák et al., 2013) The concept of CSR belongs among the concepts that deal with how to make business well that results should be beneficial not only for the company itself but also its general surroundings (or the whole society). Discussions about CSR and research itself in this area are just no longer a matter of foreign universities, but Slovak universities are also involved in contributing to the expansion of the database of knowledge in the subject matter. 
Following the research of education process in the field of CSR, particular universities need to clarify basic questions:

- Is the concept of CSR really an innovation requiring e.g. introduction of a new separate course or is it just a clearer and more logical summary of all knowledge and efforts universities already provided a long time ago, or provide their graduates within other courses, as well as the very existence and mission?

- Is it necessary to educate all students (including students of the departments of engineering and informatics) in the field of CSR or is it just a technical course for students of economics and management.

- Do businesses appreciate supply of labour force in the form of graduates being familiar and applying the principles of CSR?

- To what extent are socially responsible those (teachers, researchers) who educate and prepare future creators and actors of economic life?

The answers to these questions are still ambiguous and disputable, and therefore, they are an interesting and appropriate impulse for further research. However, authors of this article believe that even technically oriented students should have basic skills in CSR due to their better future application in labour market. "The competence of efficiency utility of knowledge and skills are the basic of the new economy. Firms and society need high competent workers" (Kucharčíková, 2014) which means that also this further alumnies f.e. in positions of project managers, resource managers, chief executives officers or as an owners have to be educated and competitively in this field. “

\section{Related works - the way to social responsibility}

„CSR is making right things even when no one required." (author unknown)

Social responsibility itself is a relatively new concept that universities, and subsequently companies and state began to be intensively interested in the second half of the $20^{\text {th }}$ century. It is not a technical invention or astonishing managerial news of recent years, because, for example Henry Ford, Henri Fayol or Tomáš Bat'a were actively engaged in issues how to improve working environment, social conditions for workers, access to nature etc. Applying the goal-orientated integration of social activities into the operation of company, they reached great business success, significant expansion of the region where the company entrenched and the increase of quality of life, not only its own employees but also the whole society. They realized that doing business just for the profit itself cannot be the long-term goal, and respected and implemented intuitively the principles that are now being explored internationally in terms of CSR. Howard R. Bowen in his book Social Responsibilities of the Businessman stated that: „CSR is social obligation- the obligation to pursue those policies, to make those decisions, or to follow those lines of action which are desirable in terms of objectives and values of our society" (Bowen, 1953) William C. Frederick, an influential contributor wrote in 1960 a definition: , [Social responsibilities] mean that businessmen should oversee the operation of an economic system that fulfils the expectations of the public. And this means in turn that the economy's means of production should be employed in such a way that production and distribution should enhance total socio-economic welfare. Social responsibility in the final analysis implies a public posture toward society's economic and human resources and a willingness to see that those resources are used for broad social ends and not simply for the narrowly circumscribed interests of private persons and firms" (Frederick, 1960, p. 60). Other definitions often used are ,CSR is an integration of companies practices and values in such a way that they are in the inclusion the interests of all stakeholders, including consumers, employees, investors and the environment" (Bussard et al., 2005), or a definition of A.B. Carroll ,, The social responsibility of business encompasses the economic, legal, ethical and discretionary expectations that a society has of organizations at a given point in time" (Carroll, 1979, p. 500). Carroll than, in 1991 revisited his four-part CSR definition: "For CSR to be accepted by the conscientious business person, it should be framed in such a way that the entire range of business responsibilities is embraced. It is suggested here that four kinds of social responsibilities constitute total CSR: economic, legal, ethical and philanthropic. Furthermore, these four categories or components of CSR might be depicted as a pyramid. To be sure, all of these kinds of responsibilities have always existed to some extent, but it has only been in recent years that ethical and philanthropic functions have taken a significant place" (Carroll, 1991, p. 40).

\subsection{Areas of social responsibility}

„One of the most important issues researches face is defining the ways of the certain gains will make“ (Durišová, 2011). The concept of CSR is able to evoke a natural purgatorial process in economically challenging times. When doing so, finance may not be only motivation, but there is a space for a new view telling that in addition to economic profit, it is also necessary to achieve so called "social profit" that the whole society can benefit from. The concept of CSR points out that economic interest may not be in contradiction with the social and environmental interests, but they can produce synergic effect. The basic principles of CSR according to ISO 26000 are:

- responsibility

- transparency,

- ethical behaviour,

- respect the interests of stakeholders,

- respect the rule of law,

- respect international standards of behaviour,

- respect human rights. 
There are so called stakeholders who are important persons implementing the concept of CSR, namely people, groups or organizations that can influence the functioning of the company. While ISO STN 26000 defines up to 7 key areas of CSR activities (administration and management of organization, human rights, HR management, environment, correct behaviour of organization, consumer affairs, involvement in community and community development) Steinerová divides the CSR activities and stakeholders into four main areas see Fig. 1 (Steinerová, 2008).

While it takes longer time when the concept of CSR was accepted as an academic discipline in Slovakia and Europe in general, there have already emerged various scientific works in this area. For example, with respect to various corporate scandals taking place in America, a group of authors examined and confirmed that there is an intellectual bias against business ethics in schools providing teaching and research in business and economics. (Hosmer,1999). A complex introductory overview of the situation in Europe was given by Mahoney (1990) when he compared teaching of business ethics in the USA schools, Great Britain and continental Europe. However, this study is limited because it is quite closely specified. A case study of the development of teaching business ethics for practice in European countries has higher informative value (Zsolnay, 1998) or in-depth surveys in various countries, especially in the UK (Cowton and Cummins, 2003; Cummins, 1999).

There are more recent studies providing an overview of teaching and research in wider area of CSR reflecting different approaches and teaching methods of European educational institutions where short courses, or education within the optional courses rather prevail. On the basis of the survey, Matten and Moon (2004) show that the most popular way how to introduce students the concept of CSR is the teaching with the use of optional courses at universities. However, many teachers and experts are the same opinion that CSR should be integrated into compulsory study programmes because student have to be aware of social and ethical dimension of his/her future business, or managerial activities. Therefore, it is not enough to integrate courses about CSR into corporate education system, but it is required in practice that each graduate should have at least basic knowledge of CSR after graduation. Only this interconnection of education system and practice can create common synergy and bring fruits in wider context in order to accomplish a vision of consensual and civilized society.

\section{Findings - education in the field of CSR in Slovakia}

If we look at the history of education and spreading of the CSR concept in Slovakia, surprisingly, it is not universities which play the first fiddle, even they are significantly behind compared to non-governmental organizations or business practice itself. The reason for this phenomenon may be found in a large diversity of the CSR activities, where the public, both in Slovakia and Czech Republic, already knew an example in our country that would also meet many assumptions of the concept of corporate social responsibility from current point of view. Tomáš Bat'a, already mentioned entrepreneur, formed a relationship to his employees on the principle of partnership and extensively influenced community and environment where his companies operated in positive way in the $20^{\prime}$ s and $30^{\prime}$ s of the twentieth century in Czechoslovakia. Many of his activities and approaches have

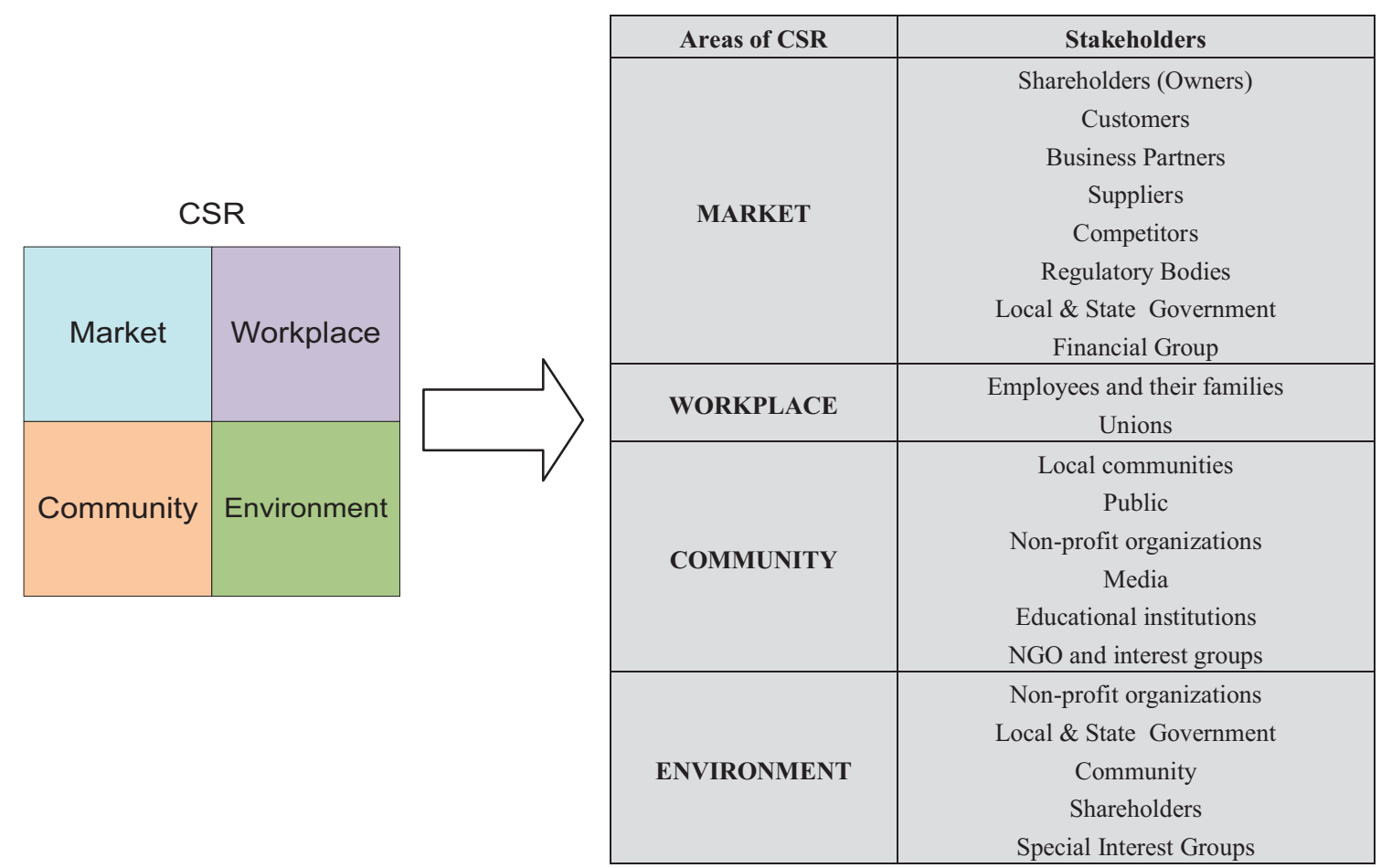

Fig. 1 Areas and stakeholders of the concept of corporate social responsibility. Source: [adjusted according to Steinerová, 2008] 
become part of the present concept of CSR, where now a number of researches continue to show that ,the concept of corporate social responsibility is perceived only roughly and rather intuitive as among the public so among entrepreneurs in our country" (Trnková, 2004; Gallová Kriglerová et al., 2007).

Since CSR is mostly understood as a covering term for a wide range of synonyms and overlapping terms, there has not been a separate course, e.g. titled Corporate Responsibility at universities so far. Students can find fragments from the CSR concept in other compulsory, selective, or optional courses, which were and are accredited at individual universities. These are the courses, for example:

- Business Ethics, Marketing, Marketing of Non-governmental Organizations,

- Ecological / Environmental Management, Sustainable Development,

- International Management, Strategic Management,

- Financial Accounting, Managerial Accounting,

- Philosophy, Sociology,

- Economics of Public Administration, Economics of Tourism.

The universities in Slovakia deal with the way how to teach the concept of CSR using project teaching and case studies in cooperation with non-governmental organizations and business practice.

Considering the corporate education and implementation of the CSR concept in Slovakia, Pontis Foundation is the pioneer of education, which has united companies practicing corporate social responsibility since 2004 and also organizes annually conference on corporate social responsibility of companies in Slovakia. As there are some companies in the Czech Republic, which are members of international platform of CSR (Business Leaders Forum), besides that Pontis Foundation conducts seminars in different regions of Slovakia for small and medium businesses, where they can learn how to do business responsibly, and this project is funded by the European Commission. Pontis Foundation has operated a public portal www.zodpovednépodnikanie.sk since 2009. (www.pontis.sk)

Another major project is the project weekly TREND, which maps the activities of companies in CSR, names trends, builds a unique register of CSR projects realized by companies at elementary, secondary schools and universities and realizes projects of informal education. In addition, it organizes a TREND CSR Barometer survey several times per year, which reflects the opinions and attitudes of special panel of participants. (www, csr.eTREND.sk)

However, it is also necessary to note that there have been born a number of recommendations at universities within scientificresearch tasks regarding the implementation of CSR to Slovak conditions for the last 2 - 3 years, but they were not adequately published such as for example at Czech universities. The universities are currently making up for missed by organizing a conference about CSR, or related topics and by way of bachelor, master and doctoral theses, which are processing this topic.

\section{Discussion - How to educate the students of Infor- matics to behave socially responsible}

Before proposing solutions to educational problem ,how to educate the students of Informatics to behave socially responsible", we have to answer the question first: „Why should we educate students of Informatics in the field of CSR?"

The arguments are as follows:

- Economic players (future employers or business partners) on the market with information -communication technology put a great accent on their reputation and credibility and thus they became leaders in the field of CSR. Naturally, they require from their employees socially responsible approach and willingness to engage in the corporate CSR activities.

- Innovative and sustainable interconnection of teaching CSR with practice supports the extent and impact of school cooperation with businesses and allows graduates to apply easily on the labour market.

- Knowledge and skills in the field of CSR contribute to the increase of professional and personal responsibilities of graduates who are seeking to improve their own lives but also the life around them. "It is necessary to prioritize the knowledge processes based on qualitative and quantitative analyses" (Litvaj et al. 2013).

- "In the time of globalisation, internetisation, social networks, information spreading and new way communication the ability to make something new, creative, efficient and unique is a key factor of success" (Soviar, Vodák, 2012).

- CSR strategy and activities are not about building brand and doing marketing activities to attract customers. It is more than "to requires managers to weigh well what to make compromises between growth, yield and risk" (Virlanuta et al. 2012)

\subsection{The proposed educational tasks and methods for teaching CSR for the students of Informatics}

It is difficult to attract students of Informatics with something else than software engineering (coding, as they call it). Therefore, educational process focused on learning the principles of corporate social responsibility should combine educational activities that are close to these students and together demonstrate effectively the use of theory in specific real business conditions. It means, that "effective performance of a university teacher involves not just the proper lecturing competence, but the application of the right methodological strategies to meet student's needs." (Durišová, 2013) “Educational activity is successful if it fulfils set learning objectives and expectations of interested subjects.” (Rostášová et al., 2013) Our proposal is the optional course „Basics of CSR” designated for students of 
II. degree of university study, which would be divided into two semesters and provided by two supervisors, namely an expert in the field of Informatics and an expert in the field of Economics. The requirement for the course would be knowledge of Informatics (e.g. web design, software, databases) and basic knowledge of Economics and Management.

The objective of this course would be to understand the importance of socially responsible behaviour, learning basic theoretical and practical knowledge and skills in that field.

Within the educational process, classical educational method in the form of lectures would be completed by the mixture of new educational methods and teaching innovations according to course schedule. By Allgood "Teaching innovations are defined as small changes in pedagogy that enable students to more quickly convert time to knowledge" (Allgood, 2001). "To achieve higher efficiency of education is necessary to use a combination of several methods. They should also include participative methods." (Kucharčíková, 2013b) It might increase the speed with which students begin to understand difficult real problem situations and also might have to effect of increasing student's interest and motivation. Suggested course schedule and mixture of new educational methods and teaching innovations for course „Basics of CSR” are followed:

\section{Semester:}

- According to education method STAD, the teacher divides the study group into 4-5 member heterogeneous groups. At the beginning, the teacher clarifies the content and then specifies the task to design CSR website. Individual teams would design and develop a website focused on the area of CSR. It could be:

- an educational site with the CSR theory and redirection to other websites with similar themes,

- CSR website of specific existing company, which informs public about made and planned CSR activities.

Monitoring and evaluation of the results of individual teams would be based on STAD.

The objective would be for students to acquire CSR terminology and theory and learn to work with the existing literature and available information and case studies in this area.

The advantage would be that their knowledge acquired in website design could be applied directly to a particular real example what would stimulate students to learn in both areas (Informatics, Economics) and make effective the whole educational process.

- Within programmed teaching, when the curriculum is divided into gradually, logically connected steps, students would use algorithms design. Algorithm design is the basis for successful software design for the students of Informatics. They could use acquired skills for algorithms design dealing with e.g. timetable draft of CSR project, budgeting CSR projects, reporting CSR projects, design of CSR projects databases, etc. The advantage of this teaching method is that it supports students in developing logic and combinational skills in solving simple tasks. It draws their attention to effective work and rational decision-making. Using the case method in the CSR classroom would be an appropriate complement of this education method, but requested three main basic steps: "first, selecting cases and integrating them into the syllabus; second, preparing student $=\mathrm{s}$ for their roles with the case method; and third, conducting the classroom discussion" (Carlson and Velenchik, 2006).

- Experiment - based on the use of brainstorming or brain writing methods, there would appear a list of creative ideas for possible CSR activities feasible in university environment. Based on discussion, survey and students' voting enrolled in the course, there would be a consensus, i.e. students would agree and work together to carry out a specific CSR plan. This form of experiential games stimulates the interest of students thanks to the real experience of theoretical knowledge applied in practice. Students would be allowed to develop:

- creative initiative in planning project activities (setting objective, searching the means to achieve it, etc.),

- ability to work in teams, to build relationships, to adapt to changes and perform necessary activities at various positions,

- organizational skills with an emphasis on efficiency and taking responsibility for their decisions,

- communication skills focused on quality and clarity of speech,

- economic and financial evaluation of the project,

- all activities relating to security and reporting of CSR activities.

\section{Semester}

- Community circle is a specific teaching method when students are able to evaluate the experiment at the beginning of the second semester, i.e. what success or failure they implemented the CSR plan with, what difficulties they came through during the implementation of CSR activities, identify false decisions and suggest improvements for future activities and compare previous theoretical knowledge with practical experience obtained. There is no one of privileged position in the community circle, i.e. the position of teacher is equal to students as well. The objective of community circle is not to teach new learning material, but train the ability to discuss, demonstrate and know how to defend own opinions and ideas, develop interpersonal relationships, strengthen the cohesion of student groups, etc. 
After a thorough evaluation of experiment, students would create 4-5 member teams again. The teacher could use a simulation method and specify the role in the educational process: Design of computer game. On the basis of knowledge and skills obtained during the previous semester and according to teacher's instructions, each group of students would be tasked to design a CSR computer game. A player could establish a virtual in this CSR game and form a strategy of CSR department as a member of management team and influence the decisions of the department. The player would be able to see the consequences of his decisions and get points, for example, for properly solved tasks. This simulation would allow teacher of "Basics of CSR” to verify to what extent students of Informatics have acquired basic knowledge and skills in the field of CSR.

Our suggested educational tasks and methods for course "basics of CSR" are : (Fig. 2)

The integral part of educational process of the course „Basics of CSR" throughout its duration would be:

- electronic communication in the form of electronic mail, mobile communications, chats, and use of various social networking tools (Twitter, Facebook) It is because "With new technology we use new tools to satisfy ancient needs and learn to use them with our limited cognitive capabilities" (Tokarčíková, 2011).

- graphic organizers supporting logical and clear layout of information and analysis of their relations, namely visualization e.g. when processing technical documents for its better understanding. Graphic organizers have different forms, from simple tables to complex images consisting of boxes, where you can enter the required information.

- CSR blogs whit post range from comments about CSR's news article clippings to long essays about CSR issues and current events. Greenlaw (2011) argues that blog can be used by students for reflection on a topic, for student discussion and as a research tool.

\section{Conclusion}

Today corporate social responsibility goes far beyond the "philanthropy" of the past, because "the present business environment is still beset by uncertainties" (Kucharčíková, 2013a) all over the world. „Continuously increasing competition and technical progress has caused that individual trade businesses begin to direct their efforts towards consumers' wishes and to be aware of their own responsibility for the welfare of society.“ (Križanová et al., 2013) The concept of CSR is able to evoke a natural purging process in economically challenging times in spite of that this concept is relatively new in Slovakia. Therefore, the key role in its promotion and teaching should play the universities that raise and educate future highly skilled workers.

The way of teaching the CSR concept has been currently solved using project teaching and case studies in Slovakia, but less (somewhere not at all) using an accredited optional or selective course. However, many critics of this state share the opinion that CSR should be integrated into the compulsory study programmes, because student has to be aware of social and ethical dimensions of his future business, or managerial activity. This article offers a view of educational methods that could be used to educate students of the study program of Informatics in field of corporate social responsibility in Slovakia. Graduating from the proposed optional course "Basics of CSR", they would obtain valuable knowledge and skills that would be able to convert later, not only into the professional field but also in drilling own socially responsible approach.

\section{Acknowledgement}

This post was created as part of application of projects: Innovation and internationalization of Education - Instrument to increase the quality of the University of Žilina in the European educational area. Modern Education for the Knowledge Society /Project is funded by EU; Grant (granted by Ministry of Education) VEGA 1/0526/13 Modelling of the multilateral relations of economic entities and improving the quality of their decisionmaking processes with ICT.

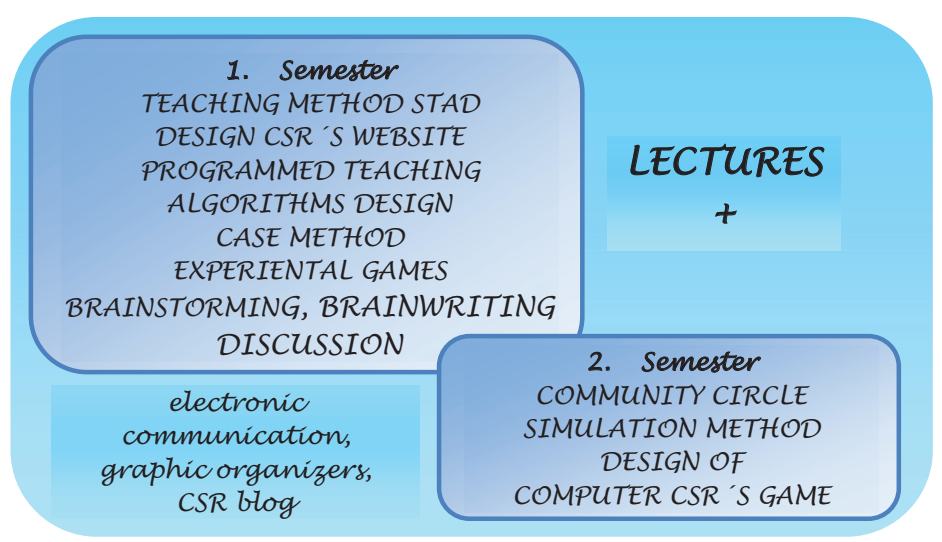

Fig. 2 Proposed educational tasks and methods for teaching CSR 


\section{References}

Allgood, S. (2001) Grade targets and teaching innovations. Economics of Education Review. 20 (5). pp. 485-493.

DOI: $10.1016 / \mathrm{s} 0272-7757(00) 00019-4$

Bowen, H. J. (1953) Social Responsibilities of the Businessman. New York: Harper Row, Bradshaw, Thornton.

Bussard, A. et al. (2005) Spoločensky zodpovedné podnikanie; Prehl'ad základných princípov a príkladov. (Corporate social responsibility; Review of basic principles and examples.). [Online] Available from: http://www. panet.sk/download/text_zodpovedne_podnikanie.pdf [Accessed: 2th September 2014]

Carlson, J., Velenchik, A. (2006) Using the Case Method in the Economics Classroom. In: Becker, M., Watts, S. Becker, W. (eds.): Teaching Economics: More Alternatives To Chalk And Talk. Edward Elgar Publishing.

Caroll, A. B. (1979) A Three-Dimensional Conceptual Model of Corporate Performance. Academy of Management Review. 4. pp. 497-505. DOI: $10.2307 / 257850$

Caroll, A. B. (1991) The Pyramid of Corporate Social Responsibility: Toward the Moral Management of Organizational Stakeholders. Business Horizons. 34 (4). pp. 39-48. DOI: 10.1016/0007-6813(91)90005-g

Cowton, C. J., Cummins, J. (2003) Teaching Business Ethics In UK Higher Education: Progress and Prospects. Teaching Business Ethics. 7. pp. 37-54.

Cummins, J. (1999) The Teaching of Business Ethics at Undergraduate, Postgraduate and Professional Levels in the UK. London: Institute of Business Ethics.

Ďrišová, M. (2011) Application of Cost Models in Transportation Companies. Periodica Polytechnica Social and Management Sciences. 19 (1). pp. 19-24. DOI: 10.3311/pp.so.2011-1.03

Ďurišová, M. (2013) Modern Methodological Approach to Teaching Business Economics For It Students. Procedia - Social and Behavioral Sciences. 106. pp. 1850-1856. DOI: 10.1016/j.sbspro.2013.12.210

Galová Kriglerová, E. et al. (2007) Východisková Správa o uplatňovaní spoločensky zodpovedného podnikania na slovensku. (Initial Report about Implementation of CSR in Slovakia). Bratislava: Regionálne Centrum Rozvojovej Pomoci OSN pre Európu s Spoločenstvo Nezávislých Štátov (United Nations Development Programme - UNDP). (In Slovakian)

Greenlaw, S. A. (2011) Augmenting Teaching and Learning with Social Software. Journal of Economic Education. 42 (1). p. 97. DOI: 10.1080/00220485.2010.500565

Hosmer, L. T. (1999) Somebody out there doesn't like us: A Study of the Position and Respect of Business Ethics At Schools of Business Administration. Journal of Business Ethics. 22. pp. 91-106.

Križanová, A., Majerová, J., Klieštik, T., Majerčák, P. (2013) Theoretical Aspects of Brand Building in Seafood Industry. Naše More = Our Sea: ZnanstvenoStručni Časopis Za More I Pomorstvo. 60 (5-6). pp. 105-112.

Kucharčíková, A. (2013a) Foreign Direct Investment in the Context of the Economic Recession in Slovakia. Journal of Finance and Economics. 1 (1). pp. 1-7. DOI: 10.12691/jfe-1-1-1

Kucharčíková, A. (2013b) The quality improvement of the university education. Procedia - Social and Behavioral Sciences. 106. pp. 2993-3001.
Kucharčíková, A. (2014) Investment in the Human Capital as the Source of Economic Growth. Periodica Polytechnica Social and Management Sciences. 22 (1). pp. 29-35. DOI: 10.3311/pp.so.7426

Litvaj, I., Poniščiaková, O., Stančeková, D., Drbúl, M. (2013) Knowledge processes and their implementation in small transport companies. Transport means 2013: proceedings of the 17th international conference. Kaunas: Kaunas University of Technology. pp. 153-156.

Lendel, V., Varmus, M. (2013) The Level of Utilization of Innovative Activities of Transport Bussinesses in the Slovak Republik. Periodica Polytechnica Social and Management Sciences. 21 (2). pp. 83-90. DOI: $10.3311 /$ ppso.7090

Mahoney, J. (1990) Teaching Business Ethics in the UK, Europe, and the USA: A Comparative Study. London: Athlone Press.

Moon, J., Matten, D. (2004) Corporate Social Responsibility Education - How and Why Europe is Different. Research Paper Series Iccsr. Nottingham.

Rostášová, M., Črejová, T., Chrenková, A. (2013) Transfer of scientific research into lifelong learning at the university of Žilina. Procedia Social And Behavioral Sciences. 106. pp. 3149-3158.

DOI: $10.1016 /$ j.sbspro.2013.12.364

Soviar, J., Vodák, J. (2012) Value network as part of new trends in communication. Communications: Scientific Letters of the University Of Žilina. 14 (2). pp. 70-75.

Steinerová, M., Makovski, D. (2008) Koncept CSR v praxi; Průvodce Zodpovědným Podnikáním (The Concept of CSR in practice; Responsible Business Guide) Aspra A.S. 32 S. (In Slovakian)

Tokarčíková, E. (2011) Influence of social networking for enterprise's activities. Periodica Polytechnica Social and Management Sciences. 19 (1). pp. 37-41. DOI: 10.3311/pp.so.2011-1.05

Tokarčíková, E. (2013) Aspects of teaching economics for students of informatics. Procedia - Social and Behavioural Sciences. 106. pp. 495-502. DOI: $10.1016 /$ j.sbspro.2013.12.055

Trnková, J. (2004) Společenská Odpovědnost Firem (Corporate Social Responsibility): Kompletni Průvodce Tématem \& Závěry Průzkumu V Čr. (Complete Guide \& Findings of the Survey In The Czech Republic). Praha: Business Leaders Forum. (In Slovakian)

Virlanuta, F. O., Muntean, M. C., Michalcea, L. (2012) The impact of economic crisis on the EU insurance market. $18^{\text {th }}$ IBIMA Conference on Innovation and sustainable Competitive Advantage: From Regional Development to World Economies. Istanbul. 9-10 May 2012. 3. pp. 1308-1312.

Vodák, J., Soviar, J., Lendel, V. (2013) Identification of the main problems in using cooperative management in Slovak enterprises and the proposal of convenient recommendations. Communications : Scientific Letters of the University of Žilina. 15 (4). pp. 63-67.

Zsolnai, L. (ed.) (1998) The European difference. Business ethics in the community of European business schools. Kluwer, Boston, Dordrecht, London. 